\title{
Prospective Teachers, Generic Skills, and Student Community Service Program: A Case Study in the Indonesian Context
}

\author{
MUHAMMAD BASRI $^{1}$, SUPARMAN ARIF ${ }^{1}$, HERYANDI $^{2}$, RISMA MARGARETHA SINAGA $^{3}$ \\ ${ }^{1}$ Department of History Education \\ Faculty of Teacher Training and Education \\ University of Lampung, INDONESIA \\ ${ }^{2}$ Faculty of Law \\ University of Lampung, INDONESIA \\ ${ }^{3}$ Postgraduate Program in Education and Social Sciences \\ University of Lampung, INDONESIA
}

\begin{abstract}
Many papers have been published in recent years describing prospective teachers' generic and teaching skills. However, to our best knowledge, little is known about how they acquire and apply these skills in real-life situations outside of the classroom, among communities through student community service program in particular. In other words, because empirical evidence in the literature has failed to recognise the implementation of prospective teachers' generic skills among communities, the question on this topic remains open. Therefore, our purpose was to explore and describe prospective teachers' generic skills when taking part in a community service program. This study is qualitative in nature, with a total of 150 students consisting of 100 females (67\%) and 50 males (33\%) enrolled at the Faculty of Teacher Training and Education in a public university in Indonesia participating by adopting a questionnaire and audio-recorded interviews for data collection. The data collected through questionnaire were analyzed using descriptive statistics, while the information collected through the interviews was evaluated and interpreted using content analysis through coding classification and theme or pattern identification, with the goal of providing thorough descriptive interpretations of social phenomena. The findings reveal that the prospective teachers under investigation strongly agree and agree that community service program has benefited them personally, socially, and professionally, as well as improved their generic skills. They could develop their generic skills while participating in a student community service program. The findings of this study provide clear evidence that generic skills and the development of these skills are deemed important by students enrolled at teacher training and education. Based on the findings, the implications and limitations of this present study with several suggestions for future research are also discussed.
\end{abstract}

Key-Words: - Community, education, teachers, social development, environment, social sciences

Received: April 6, 2021. Revised: November 12, 2021. Accepted: December 12, 2021. Published: January 9, 2022.

\section{Introduction}

Numerous articles have been published in recent years describing the generic and teaching skills of future or prospective teachers. Prospective teachers here refer to students taking a major in teacher education with the aim of becoming a teacher in the future. The higher education institution (HEI) organising the teacher training program is required to equip their graduates with skills and competencies in line with the challenges of the twenty-first century. Therefore, not only are they equipped with theoretical aspects of teaching and learning, but also the practical ones. In addition, they should also be equipped with generic skills to succeed whatever career may take them in the future. In so doing, They will be more prepared for employment once they graduate [1] from the teacher training program.

Generic skills are transferable that are part of a set of skills that increases an individual's productivity. Thus, they improve an individual's general employability by improving their ability to adapt, learn, think autonomously, make wise judgments, and cope with changes in technology. These skills are added value [2]. With this in mind, HEIs have realised the need of providing their students with skills that are in demand by industries [3], [4].

It is generally accepted that HEIs should pay more attention to their students' learning demands and be completely responsible for their students' employability after graduation [3]. Findings in the 
literature suggest that generic skills are now widely recognised as significant outcomes of university education and are included in almost every curriculum, aiding students in the acquisition not only of knowledge but also generic skills and personal qualities [5]-[7].

Moreover, the Organization for Economic Cooperation and Development (OECD) emphasises that HEIs contribute to socio-economic development through four major missions, including human capital formation, knowledge base construction, knowledge dissemination and utilisation, and knowledge maintenance [8]. This, of course, is in line with the role of HEIs to engage with communities [3], [9]. Community servicelearning has been identified as an effective method for instilling generic skills in students [10]. They further emphasise that student community services program (Indonesian: Kuliah Kerja Nyata/KKN) gives a variety of chances for developing graduate qualities in areas such as "citizenship, employability, resilience, problem-solving, and selfmotivation" [10, p. 111].

Despite the fact that policymakers, researchers, and educators have paid special attention to generic skills, to our best knowledge, little is known about how students acquire and apply these skills in reallife situations outside of the classroom, among communities through student community service program in particular. In the classroom setting, for example, separate courses have been taught to teach generic skills or the generic skills have also been trained and integrated within course subjects [11]. However, because empirical evidence in the literature has failed to recognise the implementation of prospective teachers' generic skills among communities, the question on this topic remains open. Therefore, our purpose was to explore and describe the prospective teachers' generic skills when taking part in community services.

\section{Literature Review}

\subsection{Prospective Teachers and Teacher Training Program}

Indonesia has adopted important policy reforms to promote education over the last 15 years. A constitutional mandate to spend $20 \%$ of the national budget on education, decentralising some education tasks to the district and school level, and enacting the Teacher Law in 2005 are just a few examples. In other words, communication with local governments is required to ensure the distribution of quality education [12]. Therefore, HEIs, especially those of
Teacher Training Colleges (Indonesian: Lembaga Pendidikan Tenaga Kependidikan/LPTK), play an important role to make their graduates, who are prospective teachers at the school level, move forward.

Since the enactment of the Teacher Law in 2005, educators have considered this as a vital stage in the process of improving teacher quality through teacher education programs, with new teacher competencies, such as pedagogic, personal, social, and professional being presented. This law recognises teaching as a professional occupation, requiring teachers to be certified as such [13]. However, teacher quality is a key educational issue in Indonesia that has been a central focus for years [14]. Therefore, one of the most significant components of a teacher education program is teaching practice, aimed at giving prospective teachers real-world, context-based experiences with a set of information, attitudes, and abilities that might help them attain four teacher competencies [13].

\subsection{Generic Skills}

According to National Skills Task Force (2000 as cited in [2], generic skills refer to skills that can be applied to a wide range of multiple roles. Communication, problem-solving skills, teamwork, IT abilities, number application, and the ability to increase personal learning performance are all examples of important skills. They also comprise reasoning skills, work scheduling and diagnosis, work process management skills, visualising output, working backwards for forward planning goals, and operation sequencing. As stated by [11], [15], generic skills are the prerequisites for students to be able to compete in society, education, and the workforce once their education is over. In other words, not only field-specific skills, e.g. vocational or professional skills, are required as occupational requirements, but also generic, e.g. social skills, problem-solving skills, knowledge acquisition skills, and organising skills [16], [17].

The generic skills include communication, improving own learning and development, information technology, management, numeracy, organisation of work, problem-solving, and team working [2]. It is also reported that generic skills include basic skills, teamwork, thinking skill, problem-solving, personal quality, technological skill, information management skill, entrepreneurship skill, leadership skill, and lifelong learning skill [1].

In addition to the development of generic skills in academic settings, these skills can also be 
developed in non-academic settings [6]. Thus, learning and interacting with the environment are of importance for university students [6], [18] to equip themselves in the workplace once graduation. Experiential learning, peer interactions, and other learning activities have all been found to be effective in the development of generic skills [19], [20].

\subsection{Student Community Services Program in Higher Education Institutions}

HEIs in Indonesia are required to implement the socalled Tridharma of Higher Education activities, including teaching, research, and community services [21]. Academics or university teachers are responsible for carrying out these three activities each year. In addition, university students are also required to conduct community services during their undergraduate studies through student community services program. It is experiential learning that allows students to participate in real-world activities outside of the classroom [22], [23] and into a socially and culturally diverse context through civic involvement responsibilities [24], [25]. It is also an approach for bridging the gap between HEIs and society by enhancing student civic involvement and reducing the distance between HEIs and communities [26], [27].

The student community service program is reported to have positive impacts on the development of students' academic, ethical, social, and personal domains [22], [28]-[31]. This, of course, is in accordance with HEIs' responsibilities in community engagement [3], [9]. Students can gain generic skills through community service learning, which has been proven to be an effective practice [10]. Community service provides a range of opportunities for students to build their skills such as "citizenship, employability, resilience, problem-solving, and self-motivation" [10, p. 111].

\section{Methods}

\subsection{Participants}

A total of 150 students consisting of 100 females (67\%) and 50 males (33\%) enrolled at the Faculty of Teacher Training and Education in a public university in Lampung, Indonesia, took part in the current study. They were between the ages of 21 and 23 , with an average age of 21.5 years. They majored in Social Sciences Education (38 participants), Natural Sciences Education (42 participants), Language and Arts Education (44 participants), and
Educational Science (26 participants). Figure 1 below illustrates the participants of the current study.

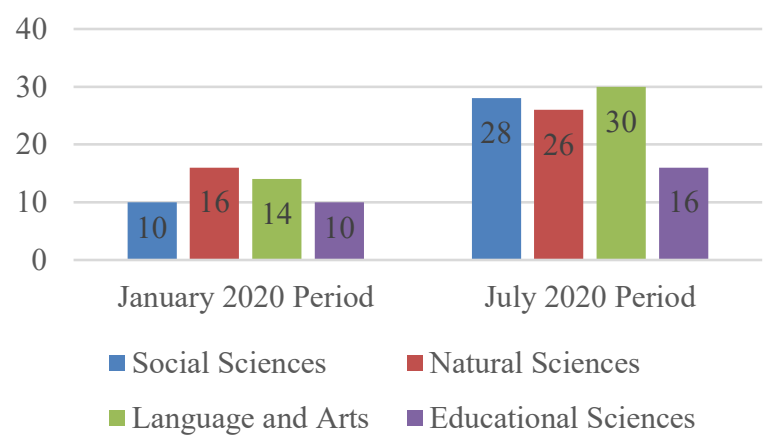

Fig. 1: Participants taking part in the study

They participated in a student community service program in rural areas in five regencies, including Tanggamus, Pringsewu, Pesawaran, South Lampung, and Central Lampung, with 50 of them taking part in January 2020 and 100 in July 2020 In the five regencies, this study was done through intensive contact with participants under investigation in a natural context, with key informants purposefully invited to take part in this study. Below is the map showing the administrative divisions of the Lampung province where the participants conducted their community service.

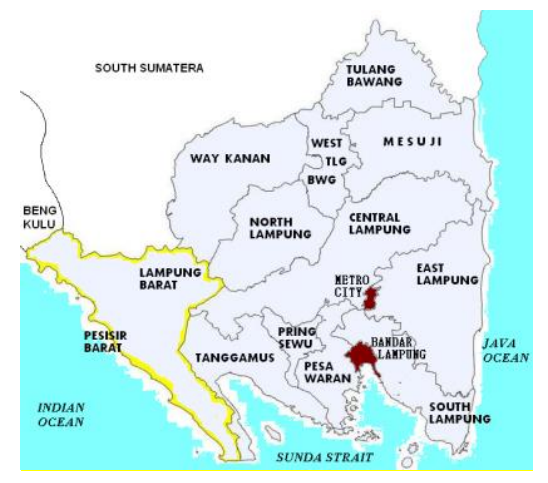

Fig. 2: Administrative divisions of Lampung Province, Indonesia

Source: [32]

The student community service program is a compulsory course with three credits for undergraduate students. Students taking part in this course live with the community for $4-8$ weeks, using a multidisciplinary and local community approach to help local people solve their problems. Although, due to a lack of resources, community service cannot have a significant impact on the students' values and cognitive development [33], however, the limited experience can help them think 
about obligations and opportunities for service, as well as people in need of social services. In other words, this program helps them increase their empathy and care, instil personality values, incorporate science and technology into collaborative and interdisciplinary projects, and so forth [33], [34]. As reported, their real-world experience can help them acquire sustainability skills [35].

\subsection{Instruments and Data Analysis}

This study adopted a qualitative approach, using a four-point Likert scale questionnaire and audiorecorded interviews for data collection [36]. The questionnaire consisted of nine statements aimed at eliciting responses from prospective teachers regarding their perceptions of how the community service program aided in the development of their generic skills. It was pilot-tested to check that the directions and statements were concise, clear, and intelligible [37]. Additionally, it was intended to examine the questionnaire's design and appropriateness for the participants, as well as to ensure that it could accomplish the aim of the research [38]. The data collected through the questionnaire were analyzed using descriptive statistics [39], while the information collected through the interviews was evaluated and interpreted using content analysis through coding classification and theme or pattern identification [40], with the goal of providing thorough descriptive interpretations of social phenomena (Tesch 1991 as cited in [41]. The coding classification or theme pattern identification was based on generic skills proposed by [2]. The collected data were then confirmed by reporting back to the key informants and triangulating them with the data collection procedures and informants to validate the authenticity and accuracy of the information. The so-called triangulation is an almost mandatory procedure for clarifying findings [36].

\section{Results}

This study was aimed at exploring and describing the prospective teachers' generic skills when taking part in a student community service program. In addition to helping communities, prospective teachers also carried out their work programs at schools where they took part in the community service program by teaching school students.

Regarding the generic skills during the community service program, at the beginning, the prospective teachers were asked about their views on the benefits of student community service program for the development of their generic skills. All of them stated that the program provided them with personal, social, and professional benefits. Figure 3 shows the evidence of the benefits.

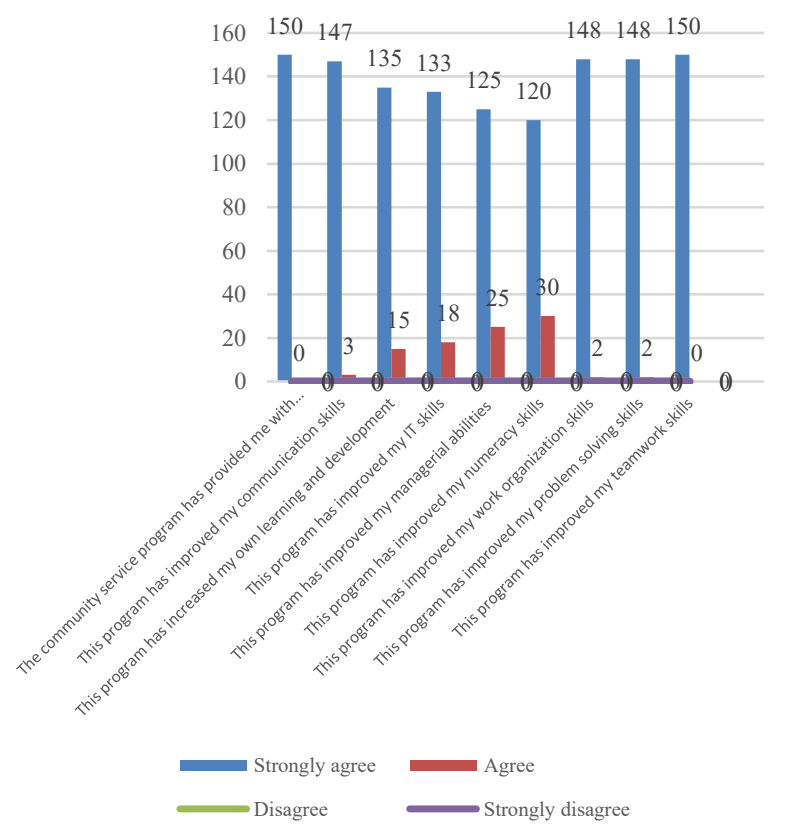

Fig. 3: Participants' perceptions on community service program

Figure 3 above illustrates the frequency and percentage of the participants showing either agreement or disagreement on the benefits of the community service program. It is apparent that overall all student participants strongly agree that the community service program they took part in has provided them with personal, social, and professional benefits $(100 \%)$. Turning to generic skills, it can be clearly seen that communication, work organization, problem solving and teamwork skills have an almost similar pattern, with communication skills having 147 participants (98\%), followed by work organization and problem solving skills with 148 participants $(98.7 \%$, respectively), and teamwork skills with 150 participants $(100 \%)$. In addition, managerial abilities, IT skills, and own learning and development also receive an almost similar pattern, ranging from $125-135$ participants $(83 \%-90 \%)$. Numeracy skill has the fewest frequency, with only 120 participants $(80 \%)$.

In addition, the responses of the interviews were coded into generic skills as stated by [2] (excerpts of translated statements with emphasis added) as follows. 


\subsection{Communication}

In terms of communication, all prospective teachers state that their communication skills have significantly improved. Here are the excerpts of translated statements with emphasis added.

My team and I always communicate our work programs, both school-based or communitybased, to the local people. We always try to convince them. (Student 8)

I have a close interaction with local people. This is real life. (Student 24)

When there were a few people rejecting my work program, I was finally able to negotiate with them. My work program ran very successfully. This was a fantastic experience. (Student 33)

I had a shy student at school. I had never successfully asked her to perform. I came up to her parents at night and talked about this to them. They allowed me to have closer contact with their child. I visited and motivated her every night, and now she has good confidence when performing in front of the class (Student 88).

\subsection{Own Learning and Development}

In terms of own learning and development, all prospective teachers state that they have learnt a lot of things. Here are the excerpts of translated statements with emphasis added.

People once said "learning cannot stop." I finally realised "yes" this is totally true. (Student 55)

I have learnt a lot from my friends and local people. They gave me advice on how to successfully complete something. A big thank you to them. I never had such experiences before I took part in this "real life" community service. (Student 68)

I should be professional and punctual. It is not just about me; it is about other people. (Student 38)

When I was appointed to work on something I never did before, and no one knew how to cope with that, I independently found out by searching on the Internet. This was a challenge, and I successfully passed it. (Student 90).

\subsection{Information Technology}

Regarding information technology, all prospective teachers state that they have learnt and done a lot of things related to the information and technology to help local people solve their problems. Here are the excerpts of translated statements with emphasis added.

I am not an expert of websites, but my knowledge of this was so helpful. I helped the village apparatus develop their village official website. I coached them as well. (Student 120)

Honestly speaking, I did not really understand Excel in detail. However, I was assigned by the village head to work on something that had to do with the Spreadsheets. It was impossible to say, "No, I don't really the complicated formulas of Excel." I learnt a lot till finally, I could complete the assignment given to me according to schedule. This was great. (Student 128)

I provided training on how to make use of simple technological tools such as email, browser, and cloud to the village apparatus to help them with their administrative work. (Student 122)

Thank God I have some understanding of information technology. Moreover, during the community services, I have improved my understanding of it since I have always been using this knowledge to help with some administrative work in the village. (Student 98).

\subsection{Management}

Regarding management, each prospective teacher states that they have developed their managerial abilities due to the community service program, as shown in the excerpts of translated statements (emphasis added) below.

We have several projects or programs to complete during this community service, and each of us plays a role as a team leader for each project. We plan and manage everything to make sure everything runs as expected. (Student 88 )

Yes, of course, we need funding for our project. We made our financial contributions, but we were also thinking of finding additional funds. We did it. (Student 72)

Some of the local people here make cassava chips and other snacks. We assist them in selling and marketing their products online. (Student $65)$. 


\subsection{Numeracy}

In terms of numeracy skill, all prospective teachers state that their numeracy skill has significantly improved. Here are the excerpts of translated statements with emphasis added.

I am not from Mathematics Department. At first, I just had an understanding of the basic numeracy level. However, let's say 'by the force of circumstance', I have developed my numeracy skill above the basic level. I successfully helped the local product producers make a business analysis. (Student 68)

I learnt Excel again. I recalled the formulas I had forgotten. It turned out the application of numbers plays an important role. (Student 19).

\subsection{Work Organisation}

In terms of organisation of work skill, all prospective teachers state that the way they organise their work has significantly improved. Here are the excerpts of translated statements with emphasis added.

To carry out our project, from planning to execution and evaluation, we do it all. (Student 121)

I can say that all of us are now multi-tasking. (Student 140)

My planning skill is now much better. When planning, I have to think of everything. This is challenging. (Student 44).

\subsection{Problem Solving}

Regarding problem solving skill, one of the most essential aspects of human cognition, each prospective teacher states that they have developed their ability to identify and resolve problems, as shown in the excerpts of translated statements (emphasis added) below.

In terms of administrative work in the village, my team and I provided the village apparatus with something innovative to make them leave out the traditional approach. (Student 90)

At my home, my bedroom has air conditioning. Here, at first, it was hard for me to fall asleep. However, finally, I could sleep well without air conditioning. It was amazing. (Student 72)
Each of us takes responsibility for a project. (Student 55)

After identifying the emerging problems here in this village, my friends and I have solved a lot of problems here. This was challenging, but we enjoyed it, really. (Student 112)

\subsection{Teamwork}

Regarding teamwork skill, each prospective teacher states that they have developed their ability to work with a group of people, as shown in the excerpts of translated statements (emphasis added) below.

In addition to working independently, I also work in a team. It is almost impossible to complete everything on our own. Teamwork plays an important role. (Student 67)

Of course, we work collaboratively, coordinate with team members, and ask for advice from the village elders and apparatus. (Student 98)

\section{Discussion}

Based on the findings of the current study, the student participants under investigation strongly agree and agree that the community service program has benefited them personally, socially, and professionally, as well as improved their generic skills. This is in line with what has been found by [42], [43] that students gained autonomy through real-world experiences, enhanced self-confidence and personal growth, gained fresh insights into the functioning of community service organizations, and progressed toward being responsible citizens.

In addition, it is evident that prospective teachers inevitably apply key generic skills, including communication, own learning and development, information technology, numeracy (application of numbers), teamwork, and problem-solving. In addition, they also develop the other two generic skills, including management and work organisation [2]. Thus, the student community service program is also a course with a component of professional experience for the prospective teachers [44]. In so doing, they have a chance to practice and develop a set of generic skills (essential general abilities) underpinning their success in education, career, lifelong learning, and personal growth [2], [22], [45] as well as "citizenship, employability, resilience, problem-solving, and self-motivation" [10, p. 111].

Through the student community service program, prospective teachers can show a strong concern for 
democratic participation and a commitment to it in order to collaborate with others and develop common understandings that encourage collaborative action, working with a variety of stakeholders to improve existing conditions both within and outside the school [46]. Moreover, when working on community-engaged projects, they find it useful as a way to foster complex and flexible community understandings, which could lead to a more sociocultural understanding of teaching as community-oriented practice in the long run [47]. In other words, they develop their areas of knowledge and other important domains, e.g. ethical, social, and personal domains [22], [28]-[31], which is in line with HEIs' responsibilities in community engagement [3], [9].

In addition, this has also resulted in the development of a very meaningful and long-term community capacity, providing novice teachers with an innovative way to teaching careers [48]. They are trained in a 'real laboratory', taking an active role in building their knowledge in the context of a larger community [48], [49]. This intervention has the potential to positively impact students' personal development, knowledge, skills, and attitudes, all of which are considered required for employment in today's workplace and society [48]. In other words, the finding of this study is also in line with what is stated [11], [15] that students must have generic abilities in order to compete in society, education, and the workforce once their formal education is over since the field-specific abilities are insufficient for occupational requirements [16], [17].

Looking at the finding of the current study, it is also apparent that prospective teachers place a great value on generic skills of which these skills are also of importance in real classrooms [15], [16], transferred through, among others, group discussions, topic presentations, and projects [11], [15]. This finding also resonates with another finding that states studying and interacting with the real environment are fundamental for students of HEIs [6], [18].

\section{Conclusion}

To conclude, the current study puts emphasis on the generic skills that future teachers have developed while participating in a student community service program. The findings of this study provide clear evidence that generic skills and the development of these skills are deemed important by students enrolled at teacher training and education. When they graduate and go to work as teachers, the generic skills they obtained in the community will come in handy.

Therefore, this study has several implications. We believe that this student community service program is a potential tool to enable student teachers to form connections in order to explore their generic skills and teaching practices, seeing themselves as part of a larger community than their own [50], [51]. The student community involvement appears to empower students as co-generators of knowledge by providing them with learning environments putting emphasis on community interaction [10]. After having experience in a student community service program, the student teachers, when graduating, can teach the generic skills to their students as a byproduct of subject studies integrated with particular pedagogical practices and teaching methods [11]. In addition, we should continually improve the students' community service program, because it also promotes the government's newly launched Freedom to Learn - Independent Campus (Indonesian: Merdeka Belajar Kampus Merdeka/MBKM) policy with an emphasis on independent real-world learning. Students are given opportunities to explore their talents and abilities without being constrained by rigid constraints that could stifle their creativity. Through this policy, it is expected that students will no longer be simple names and signatures on administrative paperwork, but rather scholars with highly-developed critical thinking and practical skills who are ready and wellprepared to meet problems in the workplace [52], [53]. Therefore, to ensure the student community service program's success, all parties, including HEIs, students, governments, communities, private sectors, and so forth, must continue to collaborate [54].

However, this study also has several limitations, leading to phenomenon under investigation, we have made a carefully considered assumption. Our findings have been interpreted as prospective teachers' perspectives on student community service programs, providing a relatively complete overview of this program in the Indonesian context. Therefore, in order to better understand this phenomenon, we emphasise the importance of undertaking additional research on this topic by observing naturally occurring community service practices in more diverse geographical areas with a larger number of student teachers and communities involved. Future research should also look at the cognitive development of community service programs in greater depth and develop an instrument to quantify it. In addition, future research needs to consider more advanced qualitative and 
quantitative data analyses. In doing so, we would be able to conclude more valid findings and conclusions, which might be used as a framework for making a significant contribution to long-term education sustainability.

\section{References:}

[1] S. Rahman, S. B. Mokhtar, and R. M. Y. M. I. M. Hamzah, "Generic skills among technical students in Malaysia," Procedia Soc. Behav. Sci., vol. 15, pp. 3713-3717, 2011, doi: 10.1016/j.sbspro.2011.04.361.

[2] J. Pumphrey and J. Slater, "An assessment of generic skills needs," London, 2002. [Online]. Available: http://dera.ioe.ac.uk/4698/1/SD13_Generic.p df.

[3] T. L. H. Nghia, "What hinders teachers from translating their beliefs into teaching behaviors: The case of teaching generic skills in Vietnamese universities," Teach. Teach. Educ., vol. 64, pp. 105-114, 2017, doi: 10.1016/j.tate.2017.02.003.

[4] D. Jackson, "An international profile of industry-relevant competencies and skill gaps in modern graduates," Int. J. Manag. Educ., vol. 8, no. 3, pp. 29-58, 2010, doi: 10.3794/ijme.83.288.

[5] S. Hande, C. A. Mohammed, and R. Komattil, "Acquisition of knowledge, generic skills and attitudes through problembased learning: Student perspectives in a hybrid curriculum," J. Taibah Univ. Med. Sci., vol. 10, no. 1, pp. 21-25, 2015, doi: 10.1016/j.jtumed.2014.01.008.

[6] W. S. C. Chan, 'Students' understanding of generic skills development in a university in Hong Kong," Procedia - Soc. Behav. Sci., vol. 2, no. 2, pp. 4815-4819, 2010, doi: 10.1016/j.sbspro.2010.03.776.

[7] Hadiyanto and M. S. Bin Ibrahim, "Students' generic skills at the National University of Malaysia and the National University of Indonesia," Procedia - Soc. Behav. Sci., vol. 83, no. 2005, pp. 71-82, 2013, doi: 10.1016/j.sbspro.2013.06.015.

[8] P. Santiago, K. Tremblay, E. Basri, and E. Arnal, Tertiary education for the knowledge society, vol. 2. Paris: OECD, 2008.

[9] P. Temple, Universities in the knowledge economy: Higher education organisation and global change. New York: Routledge, 2012.

[10] K. M. O'Connor, K. Lynch, and D. Owen,
"Student-community engagement and the development of graduate attributes," Educ. Train., vol. 53, no. 2, pp. 100-115, 2011, doi: $10.1108 / 00400911111115654$.

[11] A. Virtanen and P. Tynjälä, "Factors explaining the learning of generic skills: a study of university students' experiences," Teach. High. Educ., vol. 24, no. 7, pp. 880894, 2019, doi: 10.1080/13562517.2018.1515195.

[12] World Bank, "Improving teaching and learning in Indonesia," Where We Work, 2018.

https://www.worldbank.org/en/country/indon esia/brief/improving-teaching-and-learningin-indonesia (accessed Aug. 31, 2021).

[13] F. Faridah, A. Arismunandar, and B. Bernard, "Teaching practice, a challenge to teacher education program in Indonesia," in Proceedings of the 1st Yogyakarta International Conference on Educational Management/Administration and Pedagogy (YICEMAP 2017), 2017, vol. 66, pp. 309312, doi: 10.2991/yicemap-17.2017.54.

[14] P. Novita, "What happened to initial teacher education in Indonesia? A review of the literature," Eur. J. Soc. Sci. Educ. Res., vol. 6, no. 3, p. 88, 2019, doi: 10.26417/ejser.v6i3.p88-103.

[15] K. Bin Rakib and A. Suradin, "Adoption of generic skills in the process of teaching and learning in college of vocational," Dev. Ctry. Stud., vol. 4, no. 16, pp. 88-91, 2014.

[16] J. Arevalo, S. Pitäknen, D. Gritten, and L. Tahvanainen, "Market-relevant competencies for professional foresters in European graduate education," Int. For. Rev., vol. 12, no. 3, pp. 200-208, 2010, doi: 10.1505/ifor.12.3.200.

[17] P. Tynjälä, "Towards expert knowledge? A comparison between a constructivist and a traditional learning environment in the university," Int. J. Educ. Res., vol. 31, no. 5, pp. $357-442$, 1999, doi: 10.1016/S08830355(99)00012-9.

[18] J. G. Greeno, "Learning in activity," in The Cambridge Handbook of the Learning Sciences, R. K. Sawyer, Ed. Cambridge: Cambridge University Press, 2006.

[19] R. W. Scholz, R. Steiner, and R. Hansmann, "Role of internship in higher education in environmental sciences," J. Res. Sci. Teach., vol. 41, no. 1, pp. 24-46, 2004, doi: $10.1002 /$ tea. 10123 .

[20] J. Southcott, "Seeing the big picture: 
Experiential education in tertiary music education," J. Exp. Educ., vol. 27, no. 1, pp. 1-14, 2004, doi: $10.1177 / 105382590402700102$.

[21] Fathurrahman and A. Muhtarom, "Analysis of increasing the three pillars of higher education development in human resources behavior," 2019, doi: 10.2991/coema19.2019.42.

[22] M. Meyer, M. Neumayr, and P. Rameder, "Students' community service: Self-selection and the effects of participation," Nonprofit Volunt. Sect. Q., vol. 48, no. 6, pp. 1162 1185, 2019, doi: 10.1177/0899764019848492.

[23] S. C. Sandaran, "Service learning: Transforming students, communities and universities," Procedia - Soc. Behav. Sci., vol. 66, pp. 380-390, 2012, doi: 10.1016/j.sbspro.2012.11.281.

[24] S. A. Raskoff and R. A. Sundeen, "Cultural diversity and high school community service: The relationships between ethnicity and students' perceptions," Nonprofit Volunt. Sect. $Q$. , vol. 30, no. 4, pp. 720-746, 2001.

[25] A. S. Rusu, I. A. Copaci, and A. Soos, "The impact of service-learning on improving students' teacher training: Testing the efficiency of a tutoring program in increasing future teachers' civic attitudes, skills and self-efficacy," Procedia - Soc. Behav. Sci., vol. 203, pp. 75-83, 2015, doi: 10.1016/j.sbspro.2015.08.262.

[26] L. Benson, I. Harkavy, and J. Puckett, Dewey's dream: Universities and democracies in an age of education reform: Civil society, public schools, and democratic citizenship. Philadelphia: emple University Press, 2007.

[27] L.-J. ChanLin, H.-Y. Lin, and T.-H. Lu, "College students' service learning experiences from e-tutoring children in remote areas," Procedia - Soc. Behav. Sci., vol. 46, no. 1938 , pp. 450-456, 2012, doi: 10.1016/j.sbspro.2012.05.140.

[28] A. Astin and L. Sax, "How undergraduates are affected by service participation.," $J$. Coll. Stud. Dev., vol. 39, p. 251, 1998.

[29] M. Hooghe, "Participation in voluntary associations and value indicators: The effect of current and previous participation experiences," Nonprofit Volunt. Sect. Q., vol. 32, no. 1, pp. 47-69, 2003, doi: 10.1177/0899764003251198.

[30] S. Seider, S. C. Gillmor, and S. A.
Rabinowicz, "The impact of community service learning upon the worldviews of business majors versus non-business majors at an American university," J. Bus. Ethics, vol. 98, pp. 485-503, 2011.

[31] N. Berasategi, I. Alonso, and G. Roman, "Service-learning and higher education: Evaluating students learning process form their own percpective," Procedia - Soc. Behav. Sci., vol. 228, no. June, pp. 424-429, 2016, doi: 10.1016/j.sbspro.2016.07.065.

[32] Lampung Province, "Lampung map," Indonesia, 2021. https://archipelagofastfact.wordpress.com/20 12/08/06/lampung-province/ (accessed Sep. 22, 2021).

[33] D. E. Giles and J. Eyler, "The impact of a college community service laboratory on students' personal, social, and cognitive outcomes," Journal of Adolescence, vol. 17, no. 4. pp. 327-339, 1994, doi: 10.1006/jado.1994.1030.

[34] S. Meyers, K. Rowell, M. Wells, and B. C. Smith, "Teacher Empathy: A Model of Empathy for Teaching for Student Success," Coll. Teach., vol. 67, no. 3, pp. 160-168, 2019, doi: 10.1080/87567555.2019.1579699.

[35] I. Molderez and E. Fonseca, "The efficacy of real-world experiences and service learning for fostering competences for sustainable development in higher education," J. Clean. Prod., vol. 172, pp. 4397-4410, 2018, doi: https://doi.org/10.1016/j.jclepro.2017.04.062

[36] M. B. Miles, M. Huberman, and J. Saldana, Qualitative data analysis: A methods sourcebook, Third Edit. Los Angeles, London, New Delhi, Singapore, Washington DC: SAGE Publications Inc., 2014.

[37] E. Schleef, "Written surveys and questionnaires in sociolinguistics," in Research methods in sociolinguistics: A practical guide, First., John Wiley \& Sons, Inc., 2014, pp. 42-57.

[38] P. M. McQuirk and P. O’Neill, “Using questionnaires in qualitative human geography," in Qualitative Research Methods in Human Geography, I. Hay, Ed. Don Mills, Canada: Oxford University Press, 2016, pp. 246-273.

[39] R. Ho, Handbook of univariate and multivariate data analysis with IBM SPSS, 2nd ed. Boca Raton: CRC Press, 2014.

[40] H. F. Hsieh and S. E. Shannon, "Three approaches to qualitative content analysis," 
Qual. Health Res., vol. 15, no. 9, pp. 12771288, 2005, doi: 10.1177/1049732305276687.

[41] I. Dey, Qualitative data analysis: A userfriendly guide for social scientists. London and New York: Routledge, 2005.

[42] E. A. Parker, N. Myers, H. C. Higgins, T. Oddsson, M. Price, and T. Gould, "More than experiential learning or volunteering: a case study of community service learning within the Australian context," High. Educ. Res. I\& Dev., vol. 28, no. 6, pp. 585-596, 2009, doi: 10.1080/07294360903161147.

[43] M. F. Toncar, J. S. Reid, D. J. Burns, C. E. Anderson, and H. P. Nguyen, "Uniform Assessment of the Benefits of Service Learning: The Development, Evaluation, and Implementation of the Seleb Scale," J. Mark. Theory Pract., vol. 14, no. 3, pp. 223-238, 2006, doi: 10.2753/MTP1069-6679140304.

[44] J. Butcher et al., "Teacher education, community service learning and student efficacy for community engagement," AsiaPacific J. Teach. Educ., vol. 31, no. 2, pp. 109-124, 2003, doi: $10.1080 / 13598660301612$.

[45] M. Ibrahim, "The use of community based learning in educating college students in Midwestern USA," Procedia - Soc. Behav. Sci., vol. 2, no. 2, pp. 392-396, 2010, doi: 10.1016/j.sbspro.2010.03.032.

[46] J. Daniel, K. H. Quartz, and J. Oakes, "Teaching in community schools: Creating conditions for deeper learning," in Review of Research in Education, vol. 43, 2019, pp. 453-480.

[47] M. E. Barnes, "Contested pasts, complicated presents: Pre-service teachers' developing conceptions of community," Teach. Teach. Educ., vol. 96, p. 103152, 2020, doi: 10.1016/j.tate. 2020.103152 .

[48] G. Harfitt, "The role of the community in teacher preparation: Exploring a different pathway to becoming a teacher," Front. Educ., vol. 3, no. August, pp. 1-13, 2018, doi: $10.3389 /$ feduc. 2018.00064 .

[49] A. Furco, "Advancing service-learning at research universities," New Dir. High. Educ., vol. 2001, no. 114, pp. 67-78, 2001, doi: https://doi.org/10.1002/he.15.

[50] M. Jimenez-Silva and K. Olson, "A community of practice in teacher education: Insights and perceptions," Int. J. Teach. Learn. High. Educ., vol. 24, no. 3, pp. 335348, 2012, [Online]. Available: http://search.ebscohost.com/login.aspx?direc $\mathrm{t}=$ true $\& \mathrm{db}=$ eric\&AN=EJ1000686\& $\&$ site $=$ ehos t-live.

[51] E. Reyes-Chua, N. R. Navigar, M. J. M. Campaña, R. A. Ymana, R. J. M. Ventayen, and I. C. A. Ymana, "Reflective critical thinking skills of student leaders in higher education institutions for development," WSEAS Trans. Environ. Dev., vol. 17, pp. 418-428, 2021, doi: 10.37394/232015.2021.17.41.

[52] S. M. Murni, "The Independent Campus policy: A did to remove students' horse blinders," Tanoto Foundation, 2020. https://www.tanotofoundation.org/en/news/t he-independent-campus-policy-a-bid-toremove-students-horse-blinders/ (accessed Sep. 05, 2021).

[53] ESRI Indonesia, "The Freedom to Learn programme: GIS for everyone," 2021. https://esriindonesia.co.id/freedom-learnprogramme-gis-everyone (accessed Sep. 05, 2021).

[54] V. Tinto, "Learning better together: The impact of learning communities on student success," High. Educ. Monogr. Ser., vol. 1, no. 8, pp. 1-8, 2003.

\section{Contribution of Individual Authors to the Creation of a Scientific Article (Ghostwriting Policy)}

Muhammad Basri and Suparman Arif conceived of the presented idea.

Muhammad Basri developed the theory and performed the computations.

Heryandi and Risma Margaretha Sinaga verified the analytical methods.

All authors discussed the results and contributed to the final manuscript.

\section{Sources of Funding for Research Presented in a Scientific Article or Scientific Article Itself}

This work was supported by the University of Lampung, Grant Number: 3038/UN.26.21/PN/2020 dated 14 April 2020.

\section{Creative Commons Attribution License 4.0 (Attribution 4.0 International, CC BY 4.0)}

This article is published under the terms of the Creative Commons Attribution License 4.0 https://creativecommons.org/licenses/by/4.0/deed.en _US 